\title{
Creative Accounting Behaviour : Mencerminkan Kinerja Baik atau Menyesatkan?
}

\author{
Patmawati \\ Universitas Sriwijaya \\ Email:patmawati@fe.unsri.ac.id \\ Meita Rahmawati \\ Universitas Sriwijaya \\ Email: meita_rahmawati@unsri.ac.id \\ Efva Octavina Donata Ghozali \\ Universitas Sriwijaya \\ Email: efvagozali@unsri.ac.id
}

\begin{abstract}
This study aims to test empirically about creative accounting which is proxied by the income smoothing variable. The population used in this study were all companies listed on the Indonesia Stock Exchange, while the sample of this study were property, real estate and construction companies totaling 48 companies using purposive sampling technique. The results of this study indicate that there is a significant negative effect on the variable return on equity, current ratio, dividend payout ratio. This shows that the smaller the value of the company's return on equity, current ratio, and dividend payout ratio, the more likely the company is to do income smoothing. The results of this study also indicate that there is a significant effect of the CFO variable on income smoothing. This means that the greater the CFO of the company, the more likely the company is to do income smoothing. The results of this study provide contributions and input for the report users in seeing which companies do creative accounting so that they can decide whether to invest or not.
\end{abstract}

Keywords: Creative accounting, income smoothing, profitabilitas, deviden payout ratio, return on equity

\begin{abstract}
Abstrak
Penelitian ini bertujuan untuk menguji secara empiris tentang akuntansi kreatif (creative accounting) yang diproksikan oleh variabel perataan laba. Populasi yang digunakan dalam penelitian ini adalah semua perusahaan yang terdaftar di Bursa Efek Indonesia, sedangkan sampel penelitian ini adalah perusahaan properti, real estate dan konstruksi yang berjumlah 48 perusahaan menggunakan teknik purposive sampling. Hasil dari penelitian ini menunjukkan bahwa terdapat pengaruh negatif signifikan variabel return on equity, current ratio, deviden payout ratio. Hal ini menunjukkan bahwa semakin kecil nilai return on equity, current ratio, dan dividen payout ratio perusahaan, maka semakin besar kemungkinan perusahaan melakukan perataan laba. Hasil penelitian ini juga menunjukkan bahwa terdapat pengaruh yang signifikan variabel Cash Flows From Operating Activities (CFO) terhadap income smoothing. Hal ini berarti semakin besar Cash Flows From Operating Activities (CFO) perusahaan maka semakin besar kemungkinan perusahaan melakukan perataan laba. Dapat disimpulkan bahwa tingginya nilai laba bukan berarti menunjukkan kinerja perusahaan dalam kondisi baik. Hal ini dikarenakan adanya indikasi perusahaan melakukan perataan laba untuk tujuan tertentu. Hasil penelitian ini memberikan kontribusi dan masukan bagi para pihak pengguna laporan dalam melihat perusahaan mana saja yang melakukan creative accounting sehingga dapat memutuskan untuk menanamkan investasinya atau tidak.
\end{abstract}

Kata kunci: Creative accounting, income smoothing, profitabilitas, deviden payout ratio, return on equity

\section{Pendahuluan}

Creative accounting behaviour menjadi perhatian besar terhadap runtuhnya perusahaan-perusahaan raksasa terkait dengan adanya dugaan kecurangan (fraud), manipulasi laporaan keuangan dan adanya dugaan memoles/kosmetika akuntansi yang menyebabkan berkurangnya kepercayaan pengguna/user laporan keuangan terhadap laporan keuangan untuk memanfaatkan informasi dari laporann keuangan dalam pengambilan keputusan sehingga mengakibatkan kepercayaan terhadap profesionalisme akuntan semakin berkurang. Memudarnya tingkat kepercayaan terhadap profesionalisme akuntan berawal pada kasus Global Crossing, kasus Enron, Worldcom, HIH, Tyco, Xerox, kasus Bank Lippo, kasus PT. Citra Marga Nusapala Persada, kasus Bank Duta, PT Perusahaan Gas Negara, dan Merck 
yang runtuh satu-persatu. Disamping itu, dengan adanya sederet kecurangan pada perusahaanperusahaan seperti kasus manipulasi dalam laporan keuangan yang dilakukan manajemen PT. Bank Lippo, ditambah lagi dengan penolakan laporan keuangan PT.Telkom oleh SEC yang secara langsung maupun tidak langsung mengarah pada profesi akuntan dan semakin menambah tingkat ketidakpercayaan terhadap profesi akuntan. (Adhikara, 2011)

Terdapat juga kasus manipulasi laporan keuangan yang dilakukan oleh PT Kimia Farma yang merupakan salah satu produsen obat-obatan milik pemerintah di Indonesia. Berdasarkan hasil audit tanggal 31 Desember 2001 yang diaudit oleh Hans Tuanakotta \& Mustofa (HTM), manajemen Kimia Farma melaporkan laba bersih sebesar Rp 132 miliar. Akan tetapi, Kementerian BUMN dan Bapepam menilai bahwa laba bersih tersebut terlalu besar dan mengandung unsur rekayasa. Setelah dilakukan audit ulang, pada 3 Oktober 2002 laporan keuangan Kimia Farma 2001 disajikan kembali (restated), karena telah ditemukan kesalahan yang cukup mendasar. Pada laporan keuangan yang baru, keuntungan yang disajikan hanya sebesar Rp 99,56 miliar, atau lebih rendah sebesar Rp 32,6 milyar, atau $24,7 \%$ dari laba bersih awal yang dilaporkan. Kesalahan tersebut timbul pada unit Industri Bahan Baku yaitu kesalahan berupa overstated penjualan sebesar Rp 2,7 miliar, pada unit Logistik Sentral berupa overstated persediaan barang sebesar Rp 23,9 miliar, pada unit Pedagang Besar Farmasi berupa overstated persediaan sebesar Rp 8,1 miliar dan overstated penjualan sebesar Rp 10,7 miliar. (Reniashellyana, 2015)

Kesalahan penyajian yang berkaitan dengan persediaan tersebut timbul karena nilai yang ada dalam daftar harga persediaan terdapat pengelembungan harga yang dilakukan perusahaan. Sedangkan kesalahan penyajian berkaitan dengan penjualan terjadi dikarenakan terdapat pencatatan ganda atas penjualan. Pencatatan ganda tersebut dilakukan pada unit-unit yang tidak disampling oleh auditor, sehingga tidak berhasil dideteksi. Berdasarkan penyelidikan Bapepam, disebutkan bahwa KAP yang mengaudit laporan keuangan PT Kimia Farma telah mengikuti standar audit yang berlaku, namun gagal mendeteksi kecurangan tersebut. (Dharmawangsa, 2020)

Kasus yang baru terjadi di Indonesia pada tahun 2018 yaitu skandal laporan keuangan PT.Garuda Indonesia (Persero) Tbk yang menyatakan bahwa perusahaan mendapatkan laba. Hal ini bermula ketika dua komisaris Garuda, yakni Chairal Tanjung dan Dony Oskaria, menganggap bahwa laporan keuangan Garuda Indonesia tahun 2018 tidak sesuai dengan Pernyataan Standar Akuntansi Keuangan (PSAK). Maka keduanya menolak menandatangani laporan keuangan tersebut. Menurut mereka, seharusnya Garuda Indonesia mencatatkan rugi senilai USD 244,95 juta di tahun 2018. Namun dalam laporan keuangan tahun 2018 malah tercatat perusahaan mencetak laba bersih USD 809,84 ribu, meningkat tajam dari tahun 2017 yang rugi USD 216,58 juta. Kementerian Keuangan (Kemenkeu) dan Otoritas Jasa Keuangan (OJK) sepakat menemukan adanya pelanggaran pada laporan keuangan tahunan 2018 PT Garuda Indonesia (Persero) Tbk (GIAA). Untuk itu, kedua regulator ini sepakat menjatuhkan hukuman kepada akuntan publik, kantor akuntan publik, maupun perseroan. (Kumparan, 2019)

Kasus skandal keuangan, kegagalan perusahaan, manipulasi laporan keuangan, kesalahan pemeriksaan laporan keuangan, serta rekayasa laporan keuangan terjadi bukan hanya masalah akuntan publik saja karena hal tersebut menyangkut seluruh laporan kegiatan perusahaan (financial reporting) sehingga berbagai pihak seperti akuntan manajemen, analisis keuangan, bankir bahkan regulator juga terlibat. Semua memiliki peranan yang signifikan karena biasanya aktivitas proses creative accounting tersebut dilakukan secara berjamaah karena prosesnya sangat kompleks dan prosesnya melibatkan berbagai pihak terkait. Akuntansi sebagai seni mencatat dan ilmu perekayasa memberikan peluang bagi akuntan manajemen untuk mengambil pilihan dari berbagai alternatif metode akuntansi yang dapat digunakan untuk menyusun laporan keuangan. Hal tersebut terjadi dalam pelaksanaan praktik-praktik di perusahaan dikarenakan standar akuntansi yang berlaku khususnya di Indonesia memberikan berbagai macam alternatif pilihan tersebut. 
Salah satu Creative accounting yang bisa dilakukan oleh akuntan manajemen yaitu dengan cara melakukan perataan laba (income smoothing). Selama beberapa dekade income smoothing telah banyak dibahas dalam literature akuntansi dan manajemen. Sebagian pihak menyatakan bahwa praktik income smoothing dianggap sebagai suatu tindakan yang merugikan karena tidak menggambarkan kondisi dan posisi keuangan perusahaan secara wajar. Akan tetapi, di lain pihak praktik perataan laba dianggap sebagai seni dan merupakan tindakan yang wajar sepanjang tidak melanggar standar akuntansi, meskipun dapat mengurangi keandalan laporan keuangan sehingga menimbulkan pertanyaan apakah dengan melakukan creative accounting yang diinterpretasikan melalui income smoothing mencerminkan kinerja suatu perusahaan dalam kondisi yang baik atau malah memberikan informasi laporan keuangan yang menyesatkan ? sehingga permasalahan yang akan dikaji dalam penelitian ini adalah apakah creative accounting behaviour yang diindikasikan dengan melakukan tindakan income smoothing mencerminkan kinerja perusahaan dalam kondisi baik atau malah menyesatkan?

Penelitian mengenai creative accounting telah dilakukan sebelumnya dan menghasilkan hasil yang berbeda-beda. Oleh karena itu, penelitian ini penting untuk dilakukan dan dikaji ulang. Creative accounting behaviour merupakan tindakan/perilaku yang dilakukan oleh akuntan manajemen perusahaan dengan melakukan perekayasaan laba atau lebih dikenal dengan istilah income smoothing atau perataan laba untuk tujuan tertentu. Penelitian ini merupakan penelitian pengembangan dari penelitian sebelumnya yang dilakukan oleh Sarah dan Alamsyah (2018) yang meneliti mengenai creative accounting behavior dalam perekayasaan laporan keuangan pada perusahaan manufaktur yang terdaftar di BEI. Hasil dari penelitian ini menyatakan bahwa variabel struktur pendanaan (DER) berpengaruh terhadap perataan laba, sedangkan ukuran perusahaan, kebijakan deviden dan profitabilitas tidak berpengaruh terhadap tindakan perataan laba. Penelitian ini menambahkan variabel cash flows from Operating Activities (CFO) sesuai saran dari penelitian sebelumnya. Sampel dari penelitian ini adalah perusahaan real estate, properti dan konstruksi yang terdaftar di Bursa Efek Indonesia (BEI).

\section{Literature Review}

\subsection{Teori Agensi}

Teori Agensi merupakan konsep yang menjelaskan hubungan kontraktual antara principal dan agent. pihak yang memberikan mandat kepada pihak lain yaitu agent, untuk melakukan semua kegiatan atas nama principals dalam kapasitasnya sebagai pengambil keputusan merupakan pihak principals. Teori keagenan bermaksud memecahkan masalah yang terjadi dalam hubungan keagenan. Salah satunya adalah masalah keinginan atau tujuan dari principal dan agen yang bertentangan serta bilamana prinsipal merasa kesulitan untuk menelusuri apa yang sebenarnya dilakukan oleh agent. (Arrozi, 2008).

\subsection{Creative Accounting}

Akuntansi kreatif (Creative Accounting) merupakan proses dimana beberapa pihak menggunakan kemampuan pemahamannya tentang pengetahuan akuntansi (termasuk standar, teknik, prosedur, dan sebagainya) serta menggunakannya untuk memanipulasi pelaporan keuangan (Amat et al, 1999). Sedangkan menurut Naser (1992) mendefinisikan creative accounting sebagai suatu proses manipulasi figur akuntansi dalam pengambilan keuntungan dari kelemahan peraturan akuntansi dan pemilihan dari pengukuran serta pengungkapan praktik-praktik di dalamnya untuk mengubah laporan keuangan dari apa yang harus disajikan (Arrozi, 2011). 


\subsection{Kerangka Pikir}

Berdasarkan teori agensi (Agency Theory), agent diberikan wewenang untuk mengelola sumber daya perusahaan oleh principal termasuk pendelegasian wewenang dalam pengambilan keputusan strategis. Baik principal maupun agen sama-sama mempunyai harapan atas kinerja operasional perusahaan. Pada saat kinerja perusahaan tidak mencapai hasil yang diharapkan, maka ada kemungkinan pihak agen (manajemen perusahaan) melakukan rekayasa laporan keuangan terutama melakukan manipulasi pada laporan laba rugi. Salah satu bentuk rekayasa laporan keuangan yang kerap kali dilakukan oleh manajemen adalah creative accounting dengan melakukan perataan laba (income smoothing). Adapun variabel yang mempengaruhi perataan laba (income smoothing) yaitu profitabilitas yang diproksikan oleh return on equity, cash flows from operating activities, current ratio, dan kebijakan dividen yang diproksikan oleh dividend payout ratio. Berdasarkan uraian tersebut maka kerangka penelitian ini dapat digambarkan sebagai berikut :

Gambar 1. Kerangka Pikir

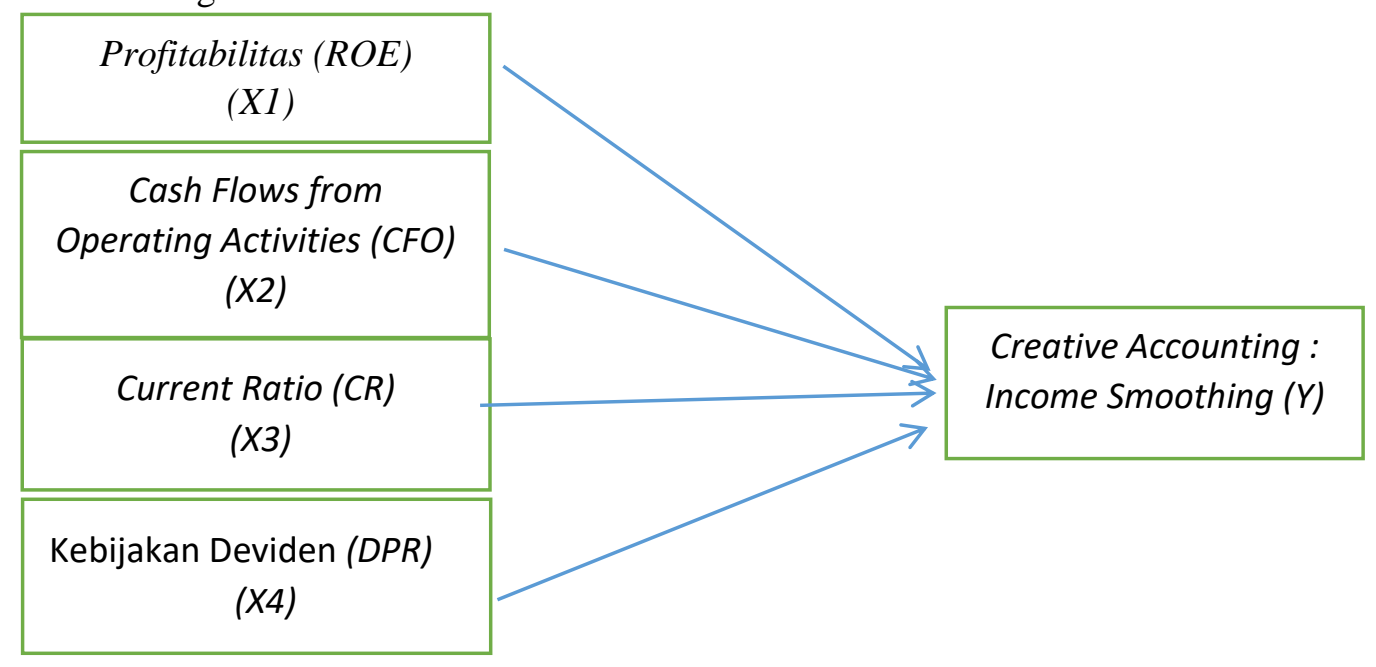

Sumber : Data Diolah, 2020

\subsection{Hipotesis Penelitian}

\subsubsection{Pengaruh Profitabilitas Terhadap Income Smoothing}

Profitabilitas diproksikan oleh variabel return on equity (ROE) adalah suatu pengukuran dari penghasilan (income) yang tersedia bagi para pemilik perusahaan (baik pemegang saham biasa maupun pemegang saham preferen) atas modal yang mereka investasikan di dalam perusahaan. Return on equity diukur dengan menggunakan rasio antara laba bersih setelah pajak dengan total modal/ekuitas. (Syamsuddin, 2009). Besarnya ROE menunjukkan tingkat hasil yang diperoleh pemilik modal atas modal yang dimiliki dalam perusahaan. Semakin tinggi rasio ini, maka menunjukkan bahwa perusahaan semakin dapat mengelola sumber dana pembiayaan operasional secara efektif untuk memperoleh laba bersih (Husaini, 2012).

H1 : Profitabilitas berpengaruh terhadap Income Smoothing

\subsubsection{Pengaruh Cash Flows From Operating Activities (CFO) Terhadap Income Smoothing}

Cash Flows from Operating Activities/CFO (arus kas dari aktivitas operasi) aktivitas penghasil utama pendapatan (revenue producting activities) dan aktivitas lainnya yang bukan merupakan aktivitas investasi dan aktivitas pendanaan. Jumlah arus kas dari aktivitas operasi merupakan indikator yang menentukan apakah operasinya perusahaan dapat menghasilkan kas yang cukup untuk melunasi pinjaman, memelihara kemampuan operasi perusahaan, membayar deviden, dan melakukan investasi baru tanpa mengandalkan pada pendanaan dari luar. Dechow and Ge (2005) menyatakan bahwa arus kas operasi berkaitan dengan kemampuan perusahaan menghasilkan laba operasi dari aspek transaksi 
bersifat kas. Untuk menghasilkan laba yang berkelanjutan perusahaan membutuhkan dukungan arus kas perusahaan.

H2 : Cash Flows from Operating Activities berpengaruh terhadap Income Smoothing

\subsubsection{Pengaruh Rasio Keuangan Terhadap Income Smoothing}

Rasio keuangan diproksikan oleh current ratio (rasio lancar) adalah rasio yang digunakan untuk mengukur kemampuan perusahaan dalam memenuhi kewajiban jangka pendek dengan aktiva lancar. Perusahaan yang memiliki current ratio (rasio lancar) rendah menunjukkan bahwa rasio likuiditas perusahaan tinggi, sedangkan rasio lancar yang tinggi akan menunjukkan adanya kelebihan aktiva lancar, yang akan memiliki pengaruh yang tidak baik terhadap profitabilitas perusahaan. Current Ratio (rasio lancar) akan mempengaruhi perubahan laba yang akan diterima perusahaan, baik itu perubahan laba yang positif maupun perubahan laba yang negatif.

H3 : Rasio Keuangan berpengaruh terhadap Income Smoothing

\subsubsection{Pengaruh Kebijakan Deviden Terhadap Income Smoothing}

Kebijakan dividen diproksikan oleh Dividend payout ratio (DPR) merupakan perbandingan antara dividen yang dibayarkan dengan laba bersih yang didapatkan dan biasanya disajikan dalam bentuk persentase. Penelitian Budiasih (2009) menyatakan bahwa Dividend Payout Ratio berpengaruh positif signifikan terhadap perataan laba dimana besar kecilnya dividen tergantung pada besar kecilnya laba yang diperoleh perusahaan. Berdasarkan penjelasan tersebut.

H4 : Kebijakan Deviden berpengaruh terhadap Income Smoothing

\section{Metodologi Penelitian}

3.1. Populasi dan Sampel

Populasi dalam penelitian ini adalah perusahaan yang terdaftar di Bursa Efek Indonesia. Sampel dalam penelitian ini adalah perusahaan properti, real estate dan konstruksi. Pengambilan sampel dengan menggunakan purposive sampling dengan kriteria yaitu perusahaan Properti, Real Estate dan Kontruksi yang terdaftar di BEI selama tahun 2016-2019, menerbitkan laporan keuangan secara lengkap dan telah diaudit, membagikan dividen kas selama tahun pengamatan. Adapun alasan dalam pemilihan sampel tersebut dikarenakan oleh setiap tahun properti dan real estate mengalami peningkatan penjualan di Indonesia. Meningkatnya penjualan properti dan real estate tentunya juga akan meningkatkan konstruksi. Penelitian ini bertujuan untuk menguji secara empiris laba yang disajikan dalam laporan keuangan apakah mencerminkan kinerja yang sebenarnya atau terdapat tindakan perekayasaan laba.

\subsection{Pengukuran dan Definisi Operasional}

Berikut definisi operasional dan pengukuran variabel pada penelitian ini, dapat dilihat pada tabel di bawah ini :

Tabel 1. Pengukuran dan Definisi Operasional

\begin{tabular}{|c|c|c|c|c|}
\hline Variabel & Definisi & Proksi & Rumus & Skala \\
\hline $\begin{array}{l}\text { Perataan laba } \\
\text { (Eckel, 1981) }\end{array}$ & $\begin{array}{l}\text { Yaitu normalisasi } \\
\text { laba yang dilakukan } \\
\text { secara sengaja } \\
\text { untuk mencapai } \\
\text { trend atau level } \\
\text { tertentu. }\end{array}$ & $\begin{array}{l}\text { Indeks } \\
\text { Eckel }\end{array}$ & $\frac{\mathrm{CV} \Delta \mathrm{I}}{\mathrm{CV} \Delta \mathrm{S}}$ & Dummy \\
\hline $\begin{array}{l}\text { Profitabilitas } \\
\text { (Syamsuddin, } \\
\text { 2009) }\end{array}$ & $\begin{array}{l}\text { Yaitu kemampuan } \\
\text { suatu perusahaan } \\
\text { dalam menghasilkan } \\
\text { laba }\end{array}$ & ROE & $\begin{array}{l}\text { Laba bersih setelah pajak } \times 100 \% \\
\text { Total Ekuitas }\end{array}$ & Rasio \\
\hline Rasio & yang & CR & Aktiva lancar x $100 \%$ & Rasio \\
\hline
\end{tabular}




\begin{tabular}{|c|c|c|c|c|}
\hline $\begin{array}{l}\text { Keuangan } \\
\text { (Brigham dan } \\
\text { Houston, } \\
(2001)\end{array}$ & $\begin{array}{lr}\text { digunakan } & \text { untuk } \\
\text { mengukur } & \\
\text { kemampuan } & \\
\text { perusahaan } & \text { dalam } \\
\text { memenuhi } & \\
\text { kewajiban } & \text { jangka } \\
\text { pendek dengan } \\
\text { aktiva lancar }\end{array}$ & & Hutang Lancar & \\
\hline $\begin{array}{l}\text { Cash Flows } \\
\text { From } \\
\text { Operating } \\
\text { Activities } \\
\text { (Dechow and } \\
\text { Ge, 2005) }\end{array}$ & $\begin{array}{ll}\text { arus kas operasi } \\
\text { berkaitan dengan } \\
\text { kemampuan } \\
\text { perusahaan } \\
\text { menghasilkan laba } \\
\text { operasi }\end{array}$ & $\mathrm{CFO}$ & $\begin{array}{l}\text { Jumlah Penerimaan kas Aktivitas } \\
\text { Operasional }\end{array}$ & Nominal \\
\hline $\begin{array}{l}\text { Kebijakan } \\
\text { Deviden } \\
\text { (Wiradharma, } \\
\text { et al: 2014). }\end{array}$ & $\begin{array}{l}\text { Yaitu besarnya laba } \\
\text { yang akan } \\
\text { dibagikan kepada } \\
\text { pemilik } \\
\text { dibandingkan } \\
\text { dengan laba bersih } \\
\text { yang diperoleh } \\
\text { perusahaan }\end{array}$ & DPR & $\begin{array}{l}\text { Deviden per Share } \\
\text { Earning per share }\end{array}$ & Rasio \\
\hline
\end{tabular}

Sumber : Data Diolah, 2020

\subsection{Metode Analisis Data}

Dalam penelitian ini menggunakan variabel dummy, variabel dummy adalah variabel yang digunakan untuk menguantitatifkan variabel yang bersifat kualitatif. (Nachrowi dan Usman, 2002). Metode dalam penelitian ini menggunakan metode pendekatan kuantitatif. Hipotesis dalam penelitian ini diuji dengan menggunakan analisis logistik. Creative accounting diproksikan dengan variabel income smoothing atau perataan laba yang merupakan variabel dummy (perataan laba $=1$, dan bukan perataan laba $=0$ ). Metode analisis yang digunakan dalam penelitian ini adalah analisis regresi logistik biner (binary logistic regression). Regresi logistik biner atau sering disingkat sebagai regresi logistik merupakan bentuk regresi khusus dimana variabel tergantung berupa variabel non-metrik, dikotomi atau biner yang menghasilkan penafsiran mirip dengan regresi linier, kegunaan utama regresi logistik ialah saat kita ingin membuat suatu model probabilitas kejadian untuk variabel tergantung kategorikal dengan keluaran bersifat dikotomi. Dalam regresi logistik probabilitas kejadian harus berada pada nilai 0 dan 1.(Hosmer dan Lemeshow, 2000)

\subsection{Uji Signifikansi Parameter}

Uji serentak parameter regresi logistik untuk mengetahui pengaruh variabel bebas terhadap variabel tidak bebas secara bersama-sama (overall) di dalam model, dapat menggunakan uji Likelihood Ratio (Hosmer dan Lemeshow, 2000).Hipotesisnya adalah sebagai berikut:

$\mathrm{H} 0: \beta 1=\beta 2=0$ (tidak ada pengaruh variabel bebas secara simultan terhadap variabel tak bebas),

H1 : minimal ada satu $\beta 10$ (ada pengaruh paling sedikit satu variabel bebas terhadap variabel tak bebas)

\subsection{Uji Parsial Parameter Regresi Logistik}

Pada umumnya, uji ini dilakukan setelah uji signifikansi model atau uji serentak memutuskan bahwa minimal ada satu variabel bebas yang memiliki pengaruh signifikan terhadap variabel bebas. Tujuannya adalah untuk mencari tahu manakah variabel bebas yang signifikan mempengaruhi 
variabel tak bebas tersebut (Hosmer dan Lemeshow, 2000). Pengujian keberartian parameter (koefisien $\beta$ ) secara parsial dapat dilakukan uji wald dengan hipotesisnya sebagai berikut: $\mathrm{H} 0=\beta \mathrm{j}=0$ (variabel bebas ke $\mathrm{j}$ tidak mempunyai pengaruh secara signifikan terhadap variabel tidak bebas)

$\mathrm{H} 1: \beta \mathrm{j}=0$ (variabel bebas ke $\mathrm{j}$ mempunyai pengaruh secara signifikan terhadap variabel bebas)

\subsection{Uji Kesesuaian Model}

Tahap selanjutnya yaitu menguji kesesuaian model (goodness of fit). Adapun hipotesis dari uji kesesuaian model yaitu:

$\mathrm{H} 0=$ Model yang dihipotesiskan sesuai dengan data .

H1 = Model yang dihipotesiskan tidak sesuai dengan data.

\section{Hasil dan Pembahasan}

\subsection{Perhitungan Indeks Eckel}

Berdasarkan hasil pemilihan sampel dengan menggunakan purposive sampling didapatkan sampel penelitian yang akan dijadikan objek penelitian ini adalah 48 perusahaan yang terdiri dari 38 perusahaan property dan real estate serta terdapat 10 perusahaan konstruksi dari total populasi perusahaan sebanyak 83 perusahaan yang terdaftar di Bursa Efek Indonesia selama periode tahun 2016 sampai dengan tahun 2019. Berdasarkan hasil analisis laporan keuangan didapatkan data mengenai perusahaan-perusahaan yang melakukan perataan laba dengan menggunakan indeks eckel sebanyak 17 perusahaan dari total 48 perusahaan yang dijadikan objek dalam penelitian ini sebagai berikut :

Tabel 2. Hasil Perhitungan Indeks Eckel

\begin{tabular}{|c|c|c|c|c|c|}
\hline No & $\begin{array}{c}\text { Kode } \\
\text { Perusahaan }\end{array}$ & $\begin{array}{c}\text { Indeks } \\
\text { Eckel }\end{array}$ & Dummy & Keterangan & Sektor Industri \\
\hline 1 & APLN & 0,80 & 1 & $\begin{array}{c}\text { Teridentifikasi income } \\
\text { smoothing }\end{array}$ & Properti dan real estate \\
\hline 2 & ELTY & 2,59 & 0 & $\begin{array}{c}\text { Tidak Teridentifikasi } \\
\text { income smoothing }\end{array}$ & Properti dan real estate \\
\hline 3 & BAPA & $-0,02$ & 1 & $\begin{array}{c}\text { Teridentifikasi income } \\
\text { smoothing }\end{array}$ & Properti dan real estate \\
\hline 4 & BEST & $-140,26$ & 1 & $\begin{array}{c}\text { Teridentifikasi income } \\
\text { smoothing }\end{array}$ & Properti dan real estate \\
\hline 5 & BIPP & $-6,40$ & 1 & $\begin{array}{c}\text { Teridentifikasi income } \\
\text { smoothing }\end{array}$ & Properti dan real estate \\
\hline 6 & BIKA & 1,77 & 0 & $\begin{array}{c}\text { Tidak Teridentifikasi } \\
\text { income smoothing }\end{array}$ & Properti dan real estate \\
\hline 7 & BKDP & 10,33 & 0 & $\begin{array}{c}\text { Tidak Teridentifikasi } \\
\text { income smoothing }\end{array}$ & Properti dan real estate \\
\hline 8 & BCIP & $-0,78$ & 1 & $\begin{array}{c}\text { Teridentifikasi income } \\
\text { smoothing }\end{array}$ & Properti dan real estate \\
\hline 9 & CTRA & 0,42 & 1 & $\begin{array}{c}\text { Teridentifikasi income } \\
\text { smoothing }\end{array}$ & Properti dan real estate \\
\hline 10 & COWL & 0,93 & 1 & $\begin{array}{c}\text { Teridentifikasi income } \\
\text { smoothing }\end{array}$ & Properti dan real estate \\
\hline 11 & DART & 0,87 & 1 & $\begin{array}{c}\text { Teridentifikasi income } \\
\text { smoothing }\end{array}$ & Properti dan real estate \\
\hline 12 & DUTI & 0,34 & 1 & $\begin{array}{c}\text { Teridentifikasi income } \\
\text { smoothing }\end{array}$ & Properti dan real estate \\
\hline
\end{tabular}




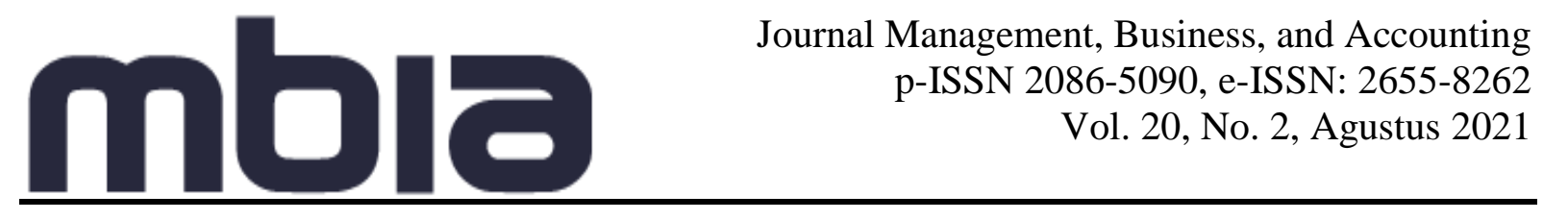

\begin{tabular}{|c|c|c|c|c|c|}
\hline 13 & LCGP & 2,27 & 0 & $\begin{array}{l}\text { Tidak Teridentifikasi } \\
\text { income smoothing }\end{array}$ & Properti dan real estate \\
\hline 14 & GAMA & 0,70 & 1 & $\begin{array}{c}\text { Teridentifikasi income } \\
\text { smoothing }\end{array}$ & Properti dan real estate \\
\hline 15 & GMTD & 0,64 & 1 & $\begin{array}{c}\text { Teridentifikasi income } \\
\text { smoothing }\end{array}$ & Properti dan real estate \\
\hline 16 & GWSA & $-0,47$ & 1 & $\begin{array}{c}\text { Teridentifikasi income } \\
\text { smoothing }\end{array}$ & Properti dan real estate \\
\hline 17 & MORE & 0,86 & 1 & $\begin{array}{c}\text { Teridentifikasi income } \\
\text { smoothing }\end{array}$ & Properti dan real estate \\
\hline 18 & DILD & $-1,03$ & 1 & $\begin{array}{c}\text { Teridentifikasi income } \\
\text { smoothing }\end{array}$ & Properti dan real estate \\
\hline 19 & KIJA & $-21,64$ & 1 & $\begin{array}{c}\text { Teridentifikasi income } \\
\text { smoothing }\end{array}$ & Properti dan real estate \\
\hline 20 & LPCK & 1,88 & 0 & $\begin{array}{l}\text { Tidak Teridentifikasi } \\
\text { income smoothing }\end{array}$ & Properti dan real estate \\
\hline 21 & LPKR & $-1,47$ & 1 & $\begin{array}{c}\text { Teridentifikasi income } \\
\text { smoothing }\end{array}$ & Properti dan real estate \\
\hline 22 & MMLP & 1,40 & 0 & $\begin{array}{l}\text { Tidak Teridentifikasi } \\
\text { income smoothing }\end{array}$ & Properti dan real estate \\
\hline 23 & EMDE & 1,80 & 0 & $\begin{array}{l}\text { Tidak Teridentifikasi } \\
\text { income smoothing }\end{array}$ & Properti dan real estate \\
\hline 24 & MTSM & $-0,25$ & 1 & $\begin{array}{l}\text { Teridentifikasi income } \\
\text { smoothing }\end{array}$ & Properti dan real estate \\
\hline 25 & MKPI & 0,64 & 1 & $\begin{array}{c}\text { Teridentifikasi income } \\
\text { smoothing }\end{array}$ & Properti dan real estate \\
\hline 26 & MTLA & 7,20 & 0 & $\begin{array}{l}\text { Tidak Teridentifikasi } \\
\text { income smoothing }\end{array}$ & Properti dan real estate \\
\hline 27 & MDLN & 0,65 & 1 & $\begin{array}{l}\text { Teridentifikasi income } \\
\text { smoothing }\end{array}$ & Properti dan real estate \\
\hline 28 & PWON & 7,77 & 0 & $\begin{array}{l}\text { Tidak Teridentifikasi } \\
\text { income smoothing }\end{array}$ & Properti dan real estate \\
\hline 29 & GPRA & 0,20 & 1 & $\begin{array}{c}\text { Teridentifikasi income } \\
\text { smoothing }\end{array}$ & Properti dan real estate \\
\hline 30 & RODA & 1,17 & 0 & $\begin{array}{l}\text { Tidak Teridentifikasi } \\
\text { income smoothing }\end{array}$ & Properti dan real estate \\
\hline 31 & PLIN & $-0,63$ & 1 & $\begin{array}{c}\text { Teridentifikasi income } \\
\text { smoothing }\end{array}$ & Properti dan real estate \\
\hline 32 & PPRO & 0,56 & 1 & $\begin{array}{c}\text { Teridentifikasi income } \\
\text { smoothing }\end{array}$ & Properti dan real estate \\
\hline 33 & RBMS & $-1,79$ & 1 & $\begin{array}{c}\text { Teridentifikasi income } \\
\text { smoothing }\end{array}$ & Properti dan real estate \\
\hline 34 & RDTX & $-1,73$ & 1 & $\begin{array}{c}\text { Teridentifikasi income } \\
\text { smoothing }\end{array}$ & Properti dan real estate \\
\hline 35 & BKSL & 0,62 & 1 & $\begin{array}{c}\text { Teridentifikasi income } \\
\text { smoothing }\end{array}$ & Properti dan real estate \\
\hline 36 & TARA & 3,50 & 0 & $\begin{array}{l}\text { Tidak Teridentifikasi } \\
\text { income smoothing }\end{array}$ & Properti dan real estate \\
\hline 37 & SMRA & $-0,86$ & 1 & $\begin{array}{c}\text { Teridentifikasi income } \\
\text { smoothing }\end{array}$ & Properti dan real estate \\
\hline 38 & SMDM & 0,44 & 1 & Teridentifikasi income & Properti dan real estate \\
\hline
\end{tabular}




\begin{tabular}{|c|c|c|c|c|c|} 
& & & & smoothing & Konstruksi \\
\hline 39 & ACST & $-3,78$ & 1 & $\begin{array}{c}\text { Teridentifikasi income } \\
\text { smoothing }\end{array}$ & Konstruksi \\
\hline 40 & ADHI & 1,10 & 0 & $\begin{array}{c}\text { Tidak Teridentifikasi } \\
\text { income smoothing }\end{array}$ & Konstruksi \\
\hline 41 & IDPR & 0,24 & 1 & $\begin{array}{c}\text { Teridentifikasi income } \\
\text { smoothing }\end{array}$ & Konstruksi \\
\hline 42 & JKON & 4,16 & 0 & $\begin{array}{c}\text { Tidak Teridentifikasi } \\
\text { income smoothing }\end{array}$ & Konstruksi \\
\hline 43 & NRCA & 1,22 & 0 & $\begin{array}{c}\text { Tidak Teridentifikasi } \\
\text { income smoothing }\end{array}$ & Konstruksi \\
\hline 44 & PTPP & 0,88 & 1 & $\begin{array}{c}\text { Teridentifikasi income } \\
\text { smoothing }\end{array}$ & Konstruksi \\
\hline 46 & TOTL & 17,69 & 0 & $\begin{array}{c}\text { Tidak Teridentifikasi } \\
\text { income smoothing }\end{array}$ & Konstruksi \\
\hline 47 & WSKT & 2,22 & 0 & $\begin{array}{c}\text { Tidak Teridentifikasi } \\
\text { income smothing }\end{array}$ & Konstruksi \\
\hline 48 & WIKA & 0,49 & 1 & $\begin{array}{c}\text { Teridentifikasi } \text { income } \\
\text { smoothing }\end{array}$ & \\
\hline
\end{tabular}

Sumber : Data Diolah, 2020

Berdasarkan tabel 2. hasil perhitungan indeks eckel dapat dilihat bahwa perusahaan yang melakukan tindakan creative accounting yang diindikasikan dengan melakukan praktik perataan laba atau_income smoothing dapat dijadikan sebagai bahan masukan bagi para pengguna laporan keuangan untuk memutuskan menanamkan investasinya atau tidak. Para pengguna laporan keuangan bisa menyimpulkan bahwa laba yang disajikan dalam laporan keuangan belum tentu menunjukkan bahwa kinerja perusahaan betul-betul dalam keadaan baik, hal ini dikarenakan adanya indikasi yang dilakukan oleh perusahaan untuk melakukan tindakan perataan laba income smoothing guna mencapai tujuan tertentu.

\subsection{Uji Signifikansi Parameter}

Berdasarkal hasil pengujian dengan menggunakan analisis regresi logistik binary dapat dilihat bahwa :

Tabel 3. Dependent Variable Encoding

\begin{tabular}{|l|c|}
\hline Original Value & Internal Value \\
\hline $\begin{array}{l}\text { Perusahaan tidak melakukan perataan } \\
\text { laba }\end{array}$ & 0 \\
\hline Perusahaan melakukan perataan laba & 1 \\
\hline
\end{tabular}

Sumber : Data Diolah, 2020

Berdasarkan Tabel 3 Dependent Variable Encoding menggambarkan hasil proses input data yang akan digunakan pada variaben dependen (respon), yaitu perusahaan tidak melakukan perataan laba diberi kode 0 dan perusahaan melakukan perataan laba diberi kode 1 (kejadian sukses terjadi Pemerataan Laba). 
Tabel 4. Classification Table

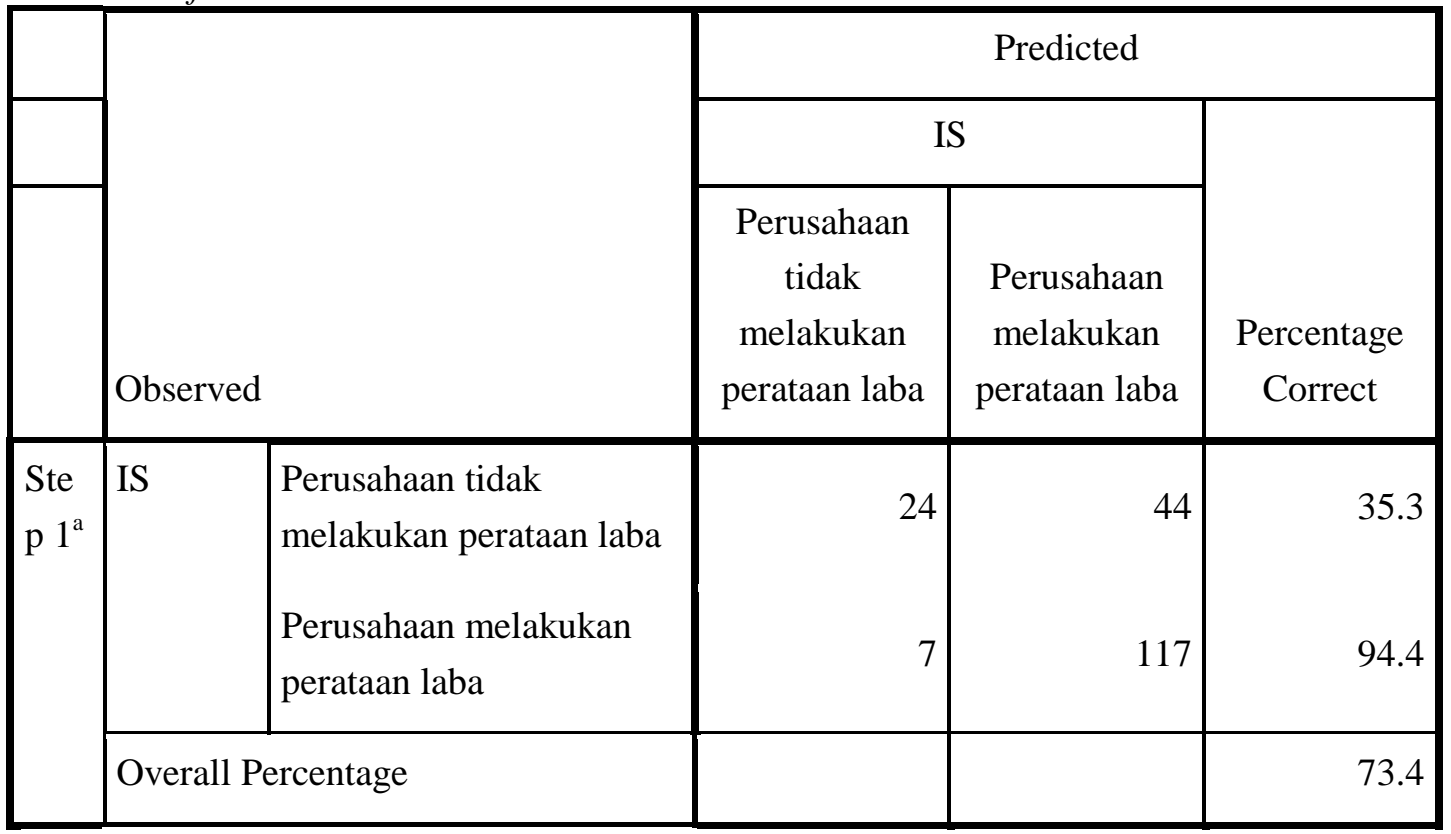

a. The cut value is .500

Sumber : Data Diolah, 2020

Berdasarkan hasil pada tabel 4.Classification Table, dapat dilihat bahwa persentase keberhasilan keseluruhan adalah sebesar $73.4 \%$. Nilai ini cukup untuk menunjukkan kebaikan model (diatas $50 \%$ ).Dapat dilihat juga hasil pengujian diperoleh Nagelkerke R Square sebesar 0,163 berdasarkan pada tabel 5. model summary dibawah ini. Hasil ini menafsirkan bahwa proporsi variabel income smoothing (IS) yang mampu dijelaskan oleh variabel profitabilitas yang diproksikan oleh return on equity (ROE), variabel rasio keuangan yang diproksikan oleh current ratio (CR), Cash Flow from Operating Acritivities (CFO), dan kebijakan deviden yang diproksikan oleh deviden payout ratio adalah sebesar $16.3 \%$.

Tabel 5. Model Summary

\begin{tabular}{|l|r|r|r|}
\hline Step & \multicolumn{1}{|c|}{$\begin{array}{c}-2 \text { Log } \\
\text { likelihood }\end{array}$} & $\begin{array}{c}\text { Cox \& Snell R } \\
\text { Square }\end{array}$ & Nagelkerke R Square \\
\hline 1 & $225.374^{\mathrm{a}}$ & .119 & .163 \\
\hline
\end{tabular}

a. Estimation terminated at iteration number 5 because parameter estimates changed by less than .001 .

Sumber : Data Diolah, 2020

4.3. Uji Parsial Parameter Regresi Logistik

Untuk mengetahui adanya pengaruh variabel-variabel prediktor secara parsial terhadap variabel respon dilakukan pengujian signifikansi koefisien-koefisien regresi secara parsial dengan menggunakan uji $\mathrm{Z}$ yang dapat dilihat pada tabel dibawah ini : 
Tabel 6. Variable in Equation

\begin{tabular}{|c|c|c|c|c|c|c|c|}
\hline & & B & S.E. & Wald & Df & Sig. & $\operatorname{Exp}(B)$ \\
\hline \multirow[t]{5}{*}{ Step $1^{\mathrm{a}}$} & ROE & -.034 & .014 & 5.998 & 1 & .014 & .966 \\
\hline & CR & -.112 & .033 & 11.136 & 1 & .001 & .894 \\
\hline & $\mathrm{CFO}$ & .018 & .009 & 3.934 & 1 & .047 & 1.018 \\
\hline & DPR & -.013 & .005 & 6.700 & 1 & .010 & .987 \\
\hline & Constant & 1.390 & .259 & 28.755 & 1 & .000 & 4.016 \\
\hline
\end{tabular}

a. Variable(s) entered on step 1: ROE, CR, CFO, DPR.

Sumber : Data Diolah, 2020

Berdasarkan hasil uji Logistic Regression yang dapat dilihat pada tabel 5. Variabel in Equation. Hipotesis yang digunakan adalah.

$\mathrm{H}_{0}: \beta_{\mathrm{j}}=0$, untuk $j=1,2, \ldots, p$.

(Tidak ada signifikansi koefisien-koefisien regresi secara parsial)

$\mathrm{H}_{1}: \beta_{\mathrm{j}} \neq 0$, untuk $j=1,2, \ldots, p$.

(Terdapat signifikansi koefisien-koefisien regresi secara parsial)

atau

$\mathrm{H}_{0}$ : Tidak ada pengaruh secara parsial variabel profitabilitas yang diproksikan oleh return on equity (ROE), variabel rasio keuangan yang diproksikan oleh current ratio (CR), variabel cash flow from operating activities (CFO), dan variabel kebijakan deviden yang diproksikan oleh deviden payout ratio (DPR) terhadap variabel creative accounting yang diproksikan oleh income smoothing (IS)

$\mathrm{H}_{1}$ : Terdapat pengaruh secara parsial variabel profitabilitas yang diproksikan oleh return on equity (ROE), variabel rasio keuangan yang diproksikan oleh current ratio (CR), variabel cash flow from operating activities (CFO), dan variabel kebijakan deviden yang diproksikan oleh deviden payout ratio (DPR) terhadap variabel creative accounting yang diproksikan oleh income smoothing (IS)

Hipotesis nol $\left(\mathrm{H}_{0}\right)$ ditolak jika Statistik Uji $|\mathrm{Z}|>\mathrm{Z}_{\alpha / 2}$ atau $\mathrm{P}$-value $\leq \alpha$ dengan tingkat signifikan $\alpha=5 \%$. Pada pengujian ini diharapkan $\mathrm{H}_{0}$ ditolak, sehingga diambil kesimpulan bahwa terdapat signifikansi koefisien-koefisien regresi secara parsial.

\subsection{Uji Kesesuaian Model}

Uji kesesuaian model digunakan untuk menguji kesesuaian model (goodness of fit) yang dapat dilihat berdasarkan hasil uji dengan menggunakan hosmer and lemeshow test dibawah ini :

Tabel 7. Homes and Lemeshow Test

\begin{tabular}{|l|r|r|r|}
\hline Step & Chi-square & Df & \multicolumn{1}{|c|}{ Sig. } \\
\hline 1 & 9.713 & 8 & .286 \\
\hline
\end{tabular}

Sumber : Data Diolah, 2020

Dapat dilihat berdasarkan tabel 4. Hosmer and Lemeshow Test, diberikan pengujian Chi-Square untuk kebaikan model dalam menjelaskan data. Pengujian ini dilakukan dengan hipotesis: 
$\mathrm{H}_{0}$ : Model telah cukup menjelaskan data (Goodness of Fit).

$\mathrm{H}_{1}$ : Model tidak cukup menjelaskan data.

Hipotesis nol diterima atau Model telah cukup menjelaskan data jika $p$-value (Sig.) $>\alpha$ dengan $\alpha=$ $5 \%$. Dari hasil output, diperoleh $p$-value (Sig.) sebesar 0.286 ( $p$-value $>5 \%$ ), sehingga disimpulkan Model telah cukup menjelaskan data. Untuk membuktikan hipotesis penelitian yang telah diajukan dapat menggunakan hasil pengujian signifikansi pada koefisien model regresi logistik. Dari output SPSS (Variables in the Equation), diperoleh Statistik Uji Wald (Wald) dan P-value (Sig.) untuk setiap variabel predictor seperti yang dapat dilihat dari hasil uji pada tabel dibawah ini :

Tabel 8. Pengujian Signifikansi pada Koefisien Model Regresi Logistik.

\begin{tabular}{|l|r|r|r|r|r|r|}
\hline Variable & \multicolumn{1}{|c|}{ B } & \multicolumn{1}{c|}{ S.E. } & \multicolumn{1}{c|}{ Wald } & \multicolumn{1}{c|}{ df } & \multicolumn{1}{c|}{ Sig. } & \multicolumn{1}{c|}{$\operatorname{Exp(B)}$} \\
\hline ROE & -0.034 & 0.014 & 5.998 & 1 & $0.014^{*}$ & .966 \\
\hline CR & -0.112 & 0.033 & 11.136 & 1 & $0.001^{*}$ & .894 \\
\hline CFO & 0.018 & 0.009 & 3.934 & 1 & $0.047^{*}$ & 1.018 \\
\hline DPR & -0.013 & 0.005 & 6.700 & 1 & $0.010^{*}$ & .987 \\
\hline Constant & 1.390 & 0.259 & 28.755 & 1 & $0.000^{*}$ & 4.016 \\
\hline
\end{tabular}

Sumber : Data Diolah, 2020

\subsection{Pengaruh Profitabilitas Terhadap Income Smoothing}

Berdasarkan hasil pengujian signifikansi pada koefisien model regresi logistik menunjukkan bahwa terdapat pengaruh negatif yang signifikan variabel profitabilitas yang diproksikan oleh return on equity (ROE) terhadap variabel creative accounting yang diproksikan oleh variabel income smoothing (IS) sebesar -0.034 (pengaruh negatif), artinya jika nilai return on equity (ROE) meningkat 1 satuan, maka hal ini akan menyebabkan adanya indikasi creative accounting yang dilakukan oleh perusahaan dengan melakukan perataan laba menurun sebesar 0.034; sebaliknya jika nilai return on equity (ROE) menurun 1 satuan, maka hal ini akan menyebabkan perusahaan melakukan perataan laba meningkat sebesar 0.034. Berdasarkan output Odd ratio $(\operatorname{Exp}(\mathrm{B}))$, diperoleh Odd ratio untuk return on equity (ROE) sebesar 0.966 . Hal ini menunjukkan bahwa return on equity (ROE) dari perusahaan tidak melakukan perataan laba adalah $1 / 0.966=1.035$ kalinya dari perusahaan melakukan perataan laba. Dapat disimpulkan bahwa (return on equity (ROE) perusahaan tidak melakukan perataan laba > return on equity (ROE) perusahaan melakukan perataan laba. Hal ini memberikan arti bahwa semakin kecil nilai return on equity (ROE) perusahaan, maka akan semakin besar kemungkinan perusahaan melakukan tindakan creative accounting dengan melakukan praktik perataan laba.

\subsection{Pengaruh Cash Flows From Operating Activities (CFO) Terhadap Income Smoothing}

Berdasarkan hasil pengujian signifikansi pada koefisien model regresi logistik menunjukkan bahwa terdapat pengaruh yang signifikan variabel cash flows from operating activities (CFO) terhadap variabel creative accounting yang diproksikan oleh income smoothing (IS) sebesar 0.018 (pengaruh positif), artinya jika nilai cash flows from operating activities (CFO) meningkat 1 satuan, maka hal ini akan menyebabkan perusahaan melakukan perataan laba meningkat sebesar 0.018; sebaliknya jika nilai cash flows from operating activities (CFO) menurun 1 satuan, maka hal ini akan menyebabkan perusahaan melakukan perataan laba menurun sebesar 0.018. Berdasarkan output Odd ratio (Exp(B),) diperoleh Odd ratio untuk cash flows from operating activities (CFO) sebesar 1.018. Hal ini mengartikan bahwa cash flows from operating activities (CFO) dari perusahaan tidak melakukan perataan laba adalah $1 / 1.018=0.982$ kalinya dari perusahaan melakukan perataan laba. Dapat disimpulkan bahwa cash flows from operating activities (CFO) perusahaan tidak melakukan perataan 
laba < cash flows from operating activities (CFO) perusahaan melakukan perataan laba. Hal ini menunjukkan bahwa semakin besar cash flows from operating activities (CFO) perusahaan, semakin besar pula kemungkinan perusahaan melakukan perataan laba.

\subsection{Pengaruh Rasio Keuangan Terhadap Income Smoothing}

Berdasarkan hasil pengujian signifikansi pada koefisien model regresi logistik menyatakan bahwa terdapat pengaruh negatif yang signifikan variabel rasio keuangan yang diproksikan oleh current ratio (CR) terhadap variabel creative accounting yang diproksikan oleh income smoothing sebesar -0.112 (pengaruh negatif), artinya jika nilai current ratio (CR) meningkat 1 satuan, maka hal ini akan menyebabkan Perusahaan melakukan perataan laba menurun sebesar 0.112 ; sebaliknya jika nilai current ratio $(\mathrm{CR})$ menurun 1 satuan, maka hal ini akan menyebabkan perusahaan melakukan perataan laba meningkat sebesar 0.112 . Berdasarkan output Odd ratio $(\operatorname{Exp}(\mathrm{B}))$, diperoleh Odd ratio untuk current ratio (CR) sebesar 0.894 . Hal ini mengartikan bahwa current ratio (CR) dari perusahaan tidak melakukan perataan laba adalah $1 / 0.894=1.119$ kalinya dari perusahaan melakukan perataan laba. Dapat disimpulkan bahwa (current ratio (CR) perusahaan tidak melakukan perataan laba > current ratio (CR) perusahaan melakukan perataan laba). Hal ini memberikan arti bahwa semakin kecil current ratio (CR) perusahaan, maka semakin besar kemungkinan perusahaan melakukan perataan laba.

\subsection{Pengaruh Kebijakan Deviden Terhadap Income Smoothing}

Berdasarkan hasil pengujian signifikansi pada koefisien model regresi logistik menunjukkan bahwa terdapat pengaruh yang signifikan variabel kebijakan deviden yang diproksikan oleh deviden payout ratio (DPR) terhadap variabel creative accounting yang diproksikan oleh income smoothing (IS) sebesar - 0.013 (pengaruh negatif), artinya jika nilai deviden payout ratio (DPR) meningkat 1 satuan, maka hal ini akan menyebabkan perusahaan melakukan perataan laba menurun sebesar 0.013; sebaliknya jika nilai deviden payout ratio (DPR) menurun 1 satuan, maka hal ini akan menyebabkan perusahaan melakukan perataan laba meningkat sebesar 0.013. Berdasarkan output Odd ratio (Exp(B)), diperoleh Odd ratio untuk variabel kebijakan deviden yang diproksikan oleh deviden payout ratio (DPR) sebesar 0.987 . Hal ini mengartikan bahwa deviden payout ratio (DPR) dari perusahaan tidak melakukan perataan laba adalah $1 / 0.987=1.013$ kalinya dari perusahaan melakukan perataan laba. Dapat disimpulkan bahwa (deviden payout ratio (DPR) perusahaan tidak melakukan perataan laba > deviden payout ratio (DPR) perusahaan melakukan perataan laba). Hal ini menunjukkan arti bahwa semakin kecil deviden payout ratio (DPR) perusahaan, semakin besar kemungkinan perusahaan melakukan perataan laba. Dari hasil pengujian yang telah dilakukan, semua variabel independen signifikan mempengaruhi variabel dependen. Model Logistic Regression dengan melibatkan semua variabel dirumuskan berikut.

$$
\begin{gathered}
\log \left(\frac{\mu_{\mathrm{i}}}{1-\mu_{\mathrm{i}}}\right)=\mathbf{x}_{\mathrm{i}}^{\prime} \boldsymbol{\beta} ; \mu_{\mathrm{i}}=\operatorname{Pr}\left(Y_{\mathrm{i}}=1 \mid \mathbf{x}_{\mathrm{i}}, \boldsymbol{\beta}\right) ; i=1,2, \ldots, n \\
\log \left(\frac{\mu_{\mathrm{i}}}{1-\mu_{\mathrm{i}}}\right)=1.390-0.034 \mathbf{R O E}-0.112 \mathbf{C R}+0.018 \mathbf{C F O}-0.013 \mathbf{D P R}+\varepsilon \\
\mu_{\mathrm{it}}=\frac{e^{1.390-0.034 \mathbf{R O E}-0.112 \mathbf{C R}+0.018 \mathbf{C F O}-0.013 \mathbf{~ D P R}}}{1+e^{1.390-0.034 \mathbf{R O E}-0.112 \mathbf{C R}+0.018 \mathbf{C F O}-0.013 \mathbf{~ D P R}}+\varepsilon}
\end{gathered}
$$

Keterangan:

$\mathrm{Y}=$ Kondisi ketika "Perusahaan melakukan perataan laba" atau "Perusahaan tidak melakukan perataan laba".

$\mu \quad=$ Probabilitas sukses terjadi adanya "Perusahaan melakukan perataan laba".

$\varepsilon \quad=$ Residual model regresi logistik biner. 


\section{Simpulan}

Berdasarkan hasil pengujian yang telah dilakukan dapat disimpulkan bahwa :

1. Terdapat pengaruh negatif yang signifikan variabel profitabilitas yang diproksikan oleh return on equity (ROE) terhadap variabel income smoothing (IS) yang berarti menunjukkan bahwa semakin kecil return on equity (ROE) perusahaan, semakin besar kemungkinan perusahaan melakukan perataan laba (income smoothing).

2. Terdapat pengaruh negatif yang signifikan variabel kinerja keuangan yang diproksikan oleh current ratio terhadap variabel income smoothing, hal ini memberikan arti bahwa semakin kecil current ratio $(\mathrm{CR})$ perusahaa maka semakin besar kemungkinan perusahaan melakukan perataan laba (income smoothing).

3. Terdapat pengaruh positif yang signifikan variabel cash flow from operating activities terhadap variabel income smoothing. Hal ini memberikan menunjukkan bahwa semakin besar cash flow from operating activities perusahaan, semakin besar kemungkinan perusahaan melakukan perataan laba (income smoothing).

4. Terdapat pengaruh yang signifikan variabel kebijakan deviden yang diproksikan oleh deviden payout ratio (DPR) terhadap variabel income smoothing (IS). Hal ini memberikan arti bahwa semakin kecil dividen payout ratio perusahaan maka semakin besar kemungkinan perusahaan melakukan perataan laba (income smoothing).

5. Perusahaan yang melakukan perataan laba (income smoothing) bisa merugikan pihak yang menggunakan informasi dalam laporan keuangan keliru dalam mengambil keputusan. Hal ini dikarenakan informasi yang terdapat pada laporan keuangan tidak mencerminkan kondisi yang sebenarnya.

\section{Daftar Pustaka}

Adhikara, MF.A. 2011. Creative Accounting : Apakah Suatu Tindakan Ilegal ? Akrual Jurnal Akuntansi 2 (2) (2011): 109-135 e-ISSN: 2502-6380

Amat O, Blake J, Jack D. 1999. The Ethics of Creative Accounting. Economics Working Paper, SSRN, December.

Arrozi MF. 2008. Creative Accounting, Working Paper Seminar Akuntansi Keperilakuan, Program Atarwaman, Rita JD. 2011. Analisis Pengaruh Ukuran Perusahaan, Profitabilitas, dan Kepemilikan Manejerial Terhadap Praktik Perataan Laba yang Dilakukan Oleh Perusahaan Manufaktur Pada Bursa Efek Indonesia. Jurnal Ilmu Ekonomi Advantage Vol. 2, No. 2.

Arrozi MF, Septyanto D. 2011. Preferensi Investor Dalam Pengambilan Keputusan Investasi Sekuritas Di Bursa Efek Indonesia, Simposim Riset Ekonomi V, ISEI, Oktober, Surabaya.

Bapepam, Kasus PT Kimia Farma Tbk, Siaran Pers Bapepam, 27 Desember 2002

Bapepam, Kasus PTBank Lippo Tbk, Siaran Pers Bapepam, 27 Desember 2002

Budiasih, Igan. 2009. Faktor - faktor yang Mempengaruhi Praktik Perataan Laba. Jurnal Akuntansi dan Bisnis, Vol 4 (1), Halaman 1-14.

Brigham, Eugene dan Joel F Houston. 2001. Manajemen Keuangan II. Jakarta: Salemba Empat.

Dechow, P. M \& Ge, W. 2005. The Persistence of Earnings and Cash Flows and the Role of Special Items. Implications for the Accrual Anomaly. Vol. 11, pp: 253-296

Dharmawangsa. $2020 . \quad$ Kronologis Kimia Farma. Diakses dari https://awen478427225086.wordpress.com/2020/10/20/kasus-manipulasi-laporan-keuanganpt-kimia-farma

Eckel N. 1981. The Income Smoothing Hypothesis Revisited. Abacus, Juni: 28-40.

Hosmer, D.W. dan Lemeshow, S. Jr..2000.Applied Logistic Regression. 2nd Edition. John Wiley \& Son, Inc, New York.

Husaini, Achmad. 2012. Pengaruh Variabel Return on Asset, Return on Equity, Net Profit Margin, dan Earning Per Share Terhadap Harga Saham Perusahaan. Jurnal Profit, Vol 6 (1), Halaman 45-49. 
Kumparan.2019. Pesawat Garuda Indonesia di landasan Terminal 3, Bandara Internasional SoekarnoHatta. Diakses dari https://kumparan.com/kumparanbisnis/fakta-fakta-skandal-laporankeuangan-garuda-1rMwNVMNWKZ

Nachrowi, N.D., dan Hardius Usman. 2002. Penggunaan Teknik Ekonometrika Pendekatan Populer dan Praktis Dilengkapi Teknik Analisis dan Pengolahan Data dengan Menggunakan Paket Program SPSS. Edisi Revisi. PT. Raja Grafindo Persada. Jakarta.

Naser K. 1992. A Note on the use of Creative Accounting. British Accounting Review, 24, pp. 111118.

Reniashellyana. 2015. Kasus Profesi Akuntansi : PT Kimia Farma. Diakses dari https://reniashellyana.wordpress.com/2015/11/

Sarah HD, Alamsyah S.2018. Creative Accounting Behavior dalam Perekayasaan Laporan Keuangan pada Perusahaan Manufaktur Terdaftar di BEI. Jurnal Online Insan Akuntan. 3 (1) : 89-100

Syamsuddin, Lukman. 2009. Manajemen Keuangan Perusahaan: Konsep Aplikasi dalam: Perencanaan, Pengawasan, dan Pengambilan Keputusan(Edisi Baru). Jakarta : Rajawali Pers.

Wiradharma, Made Swastyastu., Yuniarta, Gede Ali dan Atmadja, Ananta Wikrama Tungga. (2014). Faktor-Faktor Yang Mempengaruhi Kebijakan DPR Yang Terdaftar Di Bursa Efek Indonesia, Jurnal Akuntansi Universitas Volume 2 No 1

\section{Acknowledgement}

Peneliti mengucapkan terima kasih kepada Universitas Sriwijaya yang telah membiayai penelitian ini dengan anggaran dana DIPA PNBP Universitas Sriwijaya.

\section{Copyright Disclaimer}

Copyright for this article is retained by the author(s), with first publication rights granted to the journal. 